УДК 351.72

https://doi.org/10.32689/2708-7530-2020-1(1)-30-39

Богданенко Анатолій Іванович, кандидат наук 3 державного управління, доктор економічних наук, доцент кафедри публічного адміністрування Міжрегіональної Академії управління персоналом, 03039, м. Київ, вул. Фрометівська, 2, тел.: (044) 264-52-54, e-mail: Anatoliy_Bogdanenko@ukr.net, https//orcid.org/0000-0003-0758-5809

\title{
ВЗАСМОЗВ'ЯЗОК ЕФЕКТИВНОСТІ ДЕРЖАВНОГО УПРАВЛІННЯ ІНВЕСТИЦІЙНИМИ ПРОЦЕСАМИ У СФЕРІ БУДІВНИЦТВА СОЦІАЛЬНОГО ЖИТЛА ТА ЕКОНОМІЧНОГО ЗРОСТАННЯ В КРАЇНАХ ЄВРОПЕЙСЬКОГО СОЮЗУ
}

Анотація. На сьогоднішній день, проблема забезпечення населення соціальним житлом є надзвичайно актуальною, так як багато родин знаходяться на межі бідності і не в змозі купити собі житло, тому держава для таких сімей має бути першим захисником і помічником, створивши відповідні умови. Соціальна житлова політика в державі повинна допомагати сім'ям, які не можуть дозволити собі нормальні умови проживання.

Житлова сфера тісно пов'язана 3 усіма сферами економічного та соціального життя суспільства і відіграє важливу роль у сучасній економіці. Значною є і їі частка у валовому національному доході. Якщо у будівництво вкласти 1 гривню, то це збільшить валовий внутрішній продукт на 3 гривні, а за допомогою бюджету держави розподіляється близько $30 \%$ валового внутрішнього продукту, а додаткові надходження до бюджету, такі як податки та інші обов'язкові платежі складають приблизно 28 млрд. грн. Відповідно, ефективне функціонування житлової сфери істотно впливає на досягнення відповідного рівня розвитку економічної системи. У той же час, про недостатне задоволення житловою сферою свідчить показник забезпечення населення житлом, що в Україні становить 22,7 кв.м., що менше у порівнянні зі стандартним критерієм норми, встановленим Організацією Об'єднаних Націй, не менше ніж 30 кв.м.

Соціальна спрямованість регіонального розвитку житлового будівництва передбачає ефективне функціонування всіх його підсистем для покращення рівня і якості життя населення, як це проходить у країнах Європейського Союзу та інших розвинених країнах. У першу чергу, варто виокремити основні 
пріоритети для сталого розвитку процесу забезпечення населення України соціальним житлом та основні завдання для їх реалізації з урахуванням світового досвіду. При цьому, основна спрямованість певних зусиль держави щодо вирішення проблем будівництва соціального житла повинна створити умови для розв'язання широкого кола соціально-економічних та політичних проблем, що, зокрема, дасть потужний імпульс розвитку вітчизняної будівельної галузі, що, в свою чергу, позитивно вплине на економіку України, в цілому. Це дозволить, в умовах нестабільної економічної ситуації в світі, забезпечити стабільний економічний розвиток країни.

Ключові слова: державне управління, будівництво соціального житла, соціальне будівництво, державне управління інвестиційними процесами.

Bogdanenko Anatoliy Ivanovych, Ph.D. in public administration, Doctor of Science in Economics, Associate Professor of Public Administration Department of Interregional Academy of Personnel Management, 2, Frometivska st., 03039, Kyiv, phone: (044) 264-52-54, e-mail: Anatoliy_Bogdanenko@ukr.net, https//orcid.org/0000-0003-0758-5809

\title{
RELATIONSHIP BETWEEN THE EFFICIENCY OF PUBLIC MANAGEMENT OF INVESTMENT PROCESSES IN THE FIELD OF CONSTRUCTION OF SOCIAL HOUSING AND ECONOMIC GROWTH IN THE COUNTRIES OF THE EUROPEAN UNION
}

\begin{abstract}
Today, the problem of providing the population with social housing is extremely relevant, as many families are at risk of poverty and unable to buy housing, so the state should be the first protector and helper for such families, creating the appropriate conditions. Social housing policy in the state should help families who cannot afford normal living conditions.

The housing sector is closely connected with all spheres of the economic and social life of society and plays an important role in the modern economy. Its share in gross national income is also significant. If one invests 1 hryvnia in construction, it will increase the gross domestic product by 3 hryvnias. With the help of the state budget is distributed about $30 \%$ of gross domestic product, and additional budget revenues such as taxes and other mandatory payments are about 28 billion UAH. Accordingly, the effective functioning of the housing sector significantly affects the achievement of the appropriate level of development of the economic system. At the same time, the insufficient satisfaction of the housing sphere is evidenced by the indicator of providing the population with housing, which in Ukraine is 22.7 square
\end{abstract}


meters, which is less than the standard criterion set by the United Nations, not less than 30 square meters.

The social orientation of the regional development of housing construction provides for the effective functioning of all its subsystems to improve the standard and quality of life of the population, as is the case in the European Union and other developed countries. First of all, it is necessary to single out the main priorities for the sustainable development of the process of providing the population of Ukraine with social housing and the main tasks for their implementation, taking into account the world experience.

At the same time, the main focus of the state's efforts to solve the problem of building social housing should create conditions for solving a wide range of socioeconomic and political problems, which, in particular, will give a strong impetus to the domestic construction industry. And this, in turn, will have a positive impact on the economy of Ukraine, in general. This will, in an unstable economic situation in the world, ensure the stable economic development of the country.

Keywords: public administration, construction of social housing, social construction, public administration of investment processes.

Постановка проблеми. Необхідність розробки ефективної соціальної житлової політики для будівництва соціального житла визначає проблему впливу державних інвестицій на його відкритий ринок, що також потребує детального розгляду. Як показує практика західних країн, цей вплив негативно позначається на якості ринку дешевого житла. Це, в першу чергу, можна пояснити падінням попиту на таке житло, що знижує стимули для його будівництва. Існуюче житло зникає з ринку через підвищення квартплати, що робить невигідною його експлуатацію на ринку житла. Як показує практика, таке житло використовують, або не за призначенням, або воно занепадає. Тому, згодом, таке будівництво припиняє існувати на ринку дешевого житла.

Аналіз останніх публікацій за проблематикою. Серед вагомих наукових досліджень закордонних і вітчизняних вчених 3 питань ефективності державного управління інвестиційними процесами в сфері будівництва житла можна назвати праці таких науковців як В. О. Лук'янихін, О. І. Деміхов, С. Волкер, П. К. Кресл, Дж. Хіллс, Р. А. Алієв, Н. В. Кравченко, С. В. Ірхіна та багатьох інших.

Метою статті $\epsilon$ виявлення характерних особливостей та сучасних механізмів формування державного регулювання інвестиційними процесами у сфері будівництва соціального житла в країнах Свропейського Союзу та можливості їх використання в системі державного управління в Україні. 
Виклад основного матеріалу. Держава має реалізувати завдання щодо подолання житлової кризи, що повинні стати реальними стратегічними пріоритетами державної політики будівництва соціального житла. Така державна політика допоможе поліпшити демографічну ситуацію, знизить рівень соціальної напруженості, відновить довіру суспільства до уряду. Для досягнення соціальних цілей у деяких країнах існує досить великий сектор житла, що був створений i урегульований державою (наприклад, у Великобританії, Нідерландах). Як показує досвід інших країн, частка соціального житла в новобудовах європейських країн також значна. Так, у Німеччині обсяг нового доступного будівництва зберігається на рівні 20\%, в Австрії 24\%, в Данії 28\%, у Франції в останні роки спостерігається різке зростання до 20\% від загального обсягу введення житла [1].

Щодо ситуації в Україні, то подібна схема відкритого ринку досі не $\epsilon$ розвинутою. Але, оскільки, нині триває пошук інноваційних способів розвитку житлового будівництва, то інтерес представляє досвід Великої Британії щодо переходу держави на спільне, 3 приватним капіталом, фінансування для спорудження соціального житла (в даний час, цей показник становить близько $60 \%$ державних та 40\% приватних коштів). Це є основою розвитку нової форми соціального житла - житлових асоціацій. Цей новий тип соціального житла досі не здатний самостійно вирішувати житлові проблеми малозабезпечених верств населення, а зараз становить лише 3,7\% загального житлового фонду. Присутність на ринку майже вдвічі здешевлених можливостей будівництва для дуже обмеженої частини інвесторів є сильним негативним фактором для більшості інших інвесторів [2].

Практика субсидування попиту на ринку соціального житла, також, викликає багато політичних дебатів. У Великобританії, наприклад, житлові субсидії $є$ найбільш важливою частиною фінансового втручання держави на цей ринок. Вони як і раніше вважаються цільовим інструментом соціального захисту, спрямованим на підтримку найменш забезпечених груп населення, але недоліки в механізмі їх призначення призвели до збільшення бюджетних витрат та інших негативних наслідків. Субсидування платоспроможності населення як засіб соціального захисту приховує небезпеку взаємних стимулів для одержувачів, наприклад, змінити свій соціальний статус, зокрема, знайти роботу [3]. Аналітики відзначають, що кожен вид субсидії $є$ соціальним експериментом, який повинен вимірюватися і оцінюватися відносно його ефективності, щоб у разі потреби можна було внести відповідні корекції, проте, на жаль, небагато субсидій були піддані такому систематичному дослідженню, спрямованому на те, щоб переконатися в їх результативності [4]. 
Ми вважаємо, що найбільш важливим аспектом житлових субсидій є те, що вони дійсно можуть змінити поведінку споживачів і надавачів соціального житла, впливаючи на ціни на житло і будівельні послуги. Тому, по суті, житлові субсидії розробляються i надаються, щоб впливати на поведінку ринку нерухомості з метою його зміни відповідно до політичною ситуації. Серйозна нестача житлового фонду, недоступне житло і житло неадекватних стандартів, «це три типових прогалини на ринку», які часто вимагали втручання держави в тій чи іншій формі. Ці прогалини полягають в тому, що ринок не може забезпечити базову соціальну норму - доступність житла, відповідно до певних стандартів. Але ці недоречності на ринку можуть призвести до трьох принципово різних цілей житлової політики: збільшення виробництва житла, підвищення доступності житла або поліпшення житлових умов. Існують також різні способи досягнення даних цілей. Таким чином, збільшення виробництва житла вимагає: більшої кількості ресурсів, спрямованих на житлове будівництво; доступності житла, яка може бути досягнута за рахунок будівництва житла для малозабезпечених, або зниження вартості житла; поліпшення житлових умов, яке може бути досягнуто шляхом модернізації старих будівель; збільшення коштів для існування бюджетів домашніх господарств, або збільшення числа приватних домовласників, які бажають інвестувати в це покращення.

Звертаючи увагу на досвід розвинених країн, можна зробити висновок, що важливим завданням для України $є$ створення ринку, який дозволить державі максимально ефективно впливати на розвиток житла i проводити політику соціального захисту. Процеси, що відбуваються в цій галузі, є 3 кількісної та якісної точок зору лише перерозподілом житла, побудованого в минулому. Більш того, перерозподіл, особливо стосовно приватного житла, відбувається виключно в тіньовій сфері. У держави немає повної й достовірної інформації та засобів впливу на існуючий ринок найму як приватизованого житла, так і майна, що належить місцевій владі. Також, немає чіткого розуміння механізмів підтримки приватного житла для найму, що є основним засобом забезпечення мобільності населення в усьому світі, що, в свою чергу, є одним 3 основних важелів економічних перетворень [5].

Програми розвитку житлового будівництва практично завжди були найважливішою складовою частиною загальнодержавних програм виходу із економічних криз індустріально розвинутих країн у різний час. Житловий ринок має специфічні характеристики, які визначають його особливе місце в народногосподарському механізмі і $є$ причиною високого мультиплікативного ефекту в житловому будівництві [6]. Це пояснюється тим, що розвиток 
житлового будівництва тісно пов'язаний 3 іншими галузями економіки, що приводить до зростання попиту в суміжних галузях та зумовлює потреби в їх прискореному розвитку, передусім, в індустрії будівельних матеріалів, машинобудуванні, транспорті, житлово-комунальному господарстві, металургії, хімічній промисловості, деревообробній та легкій промисловостях тощо.

Зарубіжний досвід подолання кризових явищ в економіці свідчить, що саме житлове будівництво відіграло важливу роль у прискоренні розвитку інших галузей економіки і за рахунок мультиплікаційного ефекту дало змогу отримати значні прирости валового внутрішнього продукту, підвищити рівень зайнятості та виробництво продукції суміжних галузей промисловості. Крім того, житлове будівництво не лише взаємодіє із суміжними галузями будівельного виробництва, а й поширює мультиплікативний ефект на галузі легкої промисловості. Справа в тому, що у разі придбання житла населенням зростає гранична схильність до його споживання. Це пояснюється тим, що житло - це товар довготривалого використання, який постійно потребує ремонту, модернізації і облаштування. Купуючи житлову нерухомість, особа зацікавлена не тільки в підтриманні їі в належному стані, а й у створенні комфортних умов проживання. Саме тому придбання житла спричиняє попит на супутні товари і послуги, включаючи меблі, побутову техніку і додаткові предмети інтер'єру, які зазвичай не купуються, якщо воно орендується. Витрати власника житла стають доходами інших учасників економічних відносин, що сприяє збільшенню національного доходу. Мультиплікативний ефект інвестицій у житлову сферу проявляється в логічному взаємозв’язку інтегрованих 3 будівництвом галузей, що призводить до появи додаткових робочих місць, підвищення заробітної плати і, як наслідок, споживчого попиту.

Розрахунки, що випливають із структури витрат, яка склалася, на будівництво 1 кв. м. житла 3 урахуванням зростання обсягів житла i, відповідно, виробництва у суміжних галузях, показали, що зростання інвестування в будівництво може збільшити щорічні темпи зростання промислового виробництва за рахунок дії мультиплікатора житлових інвестицій на 3-5\%. Таким чином, мультиплікатор житлового сектору - це показник оцінки приросту валового внутрішнього продукту унаслідок збільшення витрат на будівництво житлової нерухомості і покращення житлових умов впродовж одного року. Розвиток житлового будівництва в економічному аспекті дає поштовх розвитку галузей економіки від тих, галузей що безпосередньо пов'язані з будівництвом житла, до супутніх. Більше того, механізми сучасного житлового ринку сприяють внутрішньому накопиченню 
коштів у державі. У макроекономічному плані розвиток житла є одним 3 головних напрямів у загальній системі відтворення робочої сили [7].

Отже, вірним шляхом сьогодні $є$ мобілізація заощаджень населення у будівництво соціального житла завдяки субсидуванню, що, також, сприятиме збільшенню величини мультиплікатора. Крім того, 1 долар капіталовкладень у соціальне житлове будівництво, залучений 3 допомогою різноманітних інструментів іпотечного ринку, дає приріст 3 долари валового внутрішнього продукту [8].

Також на основі досвіду державного регулювання цін на житлову нерухомість у західних країнах можна дійти висновку, що найбільш стабільні й ефективні ринки нерухомості функціонують у країнах, де розвинена альтернатива власність - орендне житло (як соціальне, так і комерційне) Франція, Фінляндія, Швеція, Німеччина. Орендне житло в Європі - це прибутковий і успішний вид бізнесу, що приносить своїм власникам стабільний дохід у розмірі 10-12\% річних [9].

Орендоване і соціальне житло виступає інструментом соціальної житлової політики, коли уряд намагається адекватно і своєчасно відповідати на очікування i запити суспільства, одночасно, створюючи ефект мультиплікативності своїх заходів в економіці і соціальній сфері. Не зважаючи на те, що Україна знаходиться не на одному щаблі з іншими розвинутими країнами, але спільним для українців та жителів розвинених країн світу є те, що більшість населення не в змозі придбати житло одразу. Здебільшого воно купується за рахунок заощаджень, або за допомогою іпотечних кредитів. Механізми надання кредитів відрізняються в різних країнах світу, і кожен з них має свої переваги і недоліки.

Кредити можуть надавати універсальні банки чи спеціалізовані банки, кредитно-ощадні установи. Традиційно іпотечний ринок поділяють на первинний та вторинний. До первинного належить безпосередня видача іпотечних кредитів та сплата відсотків за ними. За таким принципом функціонує німецька (збалансована, закрита) модель іпотечного кредитування та європейська (обмежено відкрита). Вторинний ринок - це не тільки надання іпотечних кредитів, але i їх рефінансування шляхом випуску іпотечних цінних паперів. Він буває одно- або дворівневим. Однорівневим вважається ринок, на якому установа, що видала кредит, випускає та розповсюджує іпотечні цінні папери. На дворівневому ринку заставні передаються спеціалізованій іпотечній установі, а та вже формує пули цінних паперів та випускає їх від свого імені. Вторинний ринок є властивим для американської (розширено-відкритої) моделі іпотечного кредитування. 
Головною метою розвитку системи іпотеки в нашій державі $\epsilon$ функціонування ринкових механізмів, які б відповідали міжнародним стандартам. Сучасний ринок іпотечного кредитування є фрагментарним. Для того, щоб мати розвинутий ринок іпотеки, вітчизняні банки повинні збільшити обсяги кредитування хоча 6 в 3 рази [10]. Кредитна активність банків, протягом досліджуваного періоду, залишалася низькою через загальну фінансову та економічну кризи, стагнаційні процеси на ринку нерухомості, зниження реальних доходів населення, високий рівень невизначеності щодо подальшого економічного розвитку та високий рівень нестабільності. вартість кредитних ресурсів. Для поліпшення ситуації держава повинна встановити загальні правила, що забезпечують ефективність взаємодії всіх учасників ринку іпотечного кредитування.

Висновки і перспективи подальших досліджень. Отже, інвестиції у будівництво соціального житла дають дійсно вищий мультиплікативний ефект, ніж інвестиції в інші сфери. Це вказує на те, що державі «вигідно» максимально застосовувати всі можливі інструменти для росту житлових інвестицій не тільки в плані вирішення соціальних проблем (забезпечення житлом населення), а й в макроекономічному плані, адже витрати в сфері житлового будівництва завдяки мультиплікації повертаються ростом валового внутрішнього продукту в ще більших масштабах. Стосовно ж державних інструментів, то пряме бюджетне фінансування будівництва житла обмежене величиною бюджетних витрат, які може дозволити з цього приводу держава. Найбільш ефективним інструментом держави, на наш погляд, є підтримка житлової іпотеки як шляхом субсидування окремих категорій громадян, так i шляхом державного сприяння розвитку цього інституту, загалом, тим більше, що житлова іпотека зарекомендувала себе в багатьох країнах ще i як ефективний інструмент не тільки макроекономічної політики, а й соціальної політики держави.

\section{Jimepamypa:}

1. Walker S., \& J. Marr (2016). Stakeholder power: a winning strategy for building stakeholder commitment and driving corporate growth. Cambridge, Mass.

2. Алієв Р.А. Теоретичні аспекти регіональної стратегії розвитку житлового будівництва [Електронний ресурс] / Р.А. Алієв // Економічний простір. - 2014. - № 90. - с. 52. - Режим доступу:http://irbis-nbuv.gov.ua/cgi-bin/irbis_nbuv/cgiirbis_64.exe?

$\mathrm{C} 21 \mathrm{COM}=2 \& \mathrm{I} 21 \mathrm{DBN}=\mathrm{UJRN}$ $\& P 21 D B N=U J R N \& I M A G E \_F I L E \_D O W N L O A D=1 \& I m a g e$ file_name=PDF/ecpros_2014_90_8. pdf.

3. Кравченко В.П. Аналіз соціальної політики України та ії ефективність на сучасному етапі [Електронний ресурс] / В.П. Кравченко, Н.В. Кравченко // Науково-інформаційний вісник Івано-Франківського університету права імені Короля Данила Галицького. - 2015. - 
№ 11. - $\quad$ с. 294 - $\quad$ - Режим доступу: http://irbis-nbuv.gov.ua/cgibin/irbis_nbuv/cgiirbis_64.exe?C21COM=2\&I21DBN=UJRN\&P21DBN=UJRN\&IMAGE_FILE_ DOWNLOAD=1\&Image_file_name=PDF/Nivif_2015_11_43.pdf.

4. Kresl P.K., \& Balwant S. (2004). The Competitiveness of Cities. Cities and the Global Economy Conference Paper. Melbourne.

5. Методика Моделювання соціально-економічного розвитку територій : наук.-метод. розробка / С.М. Ромашко, І.З. Саврас, Р.Г. Селівестов, Р.В. Юринець. - Київ : НАДУ, 2013. $44 \mathrm{c}$.

6. Орлова Н.С. Особливості реалізації державної житлової політики в Україні / Н.С. Орлова // Наукові праці [Чорноморського державного університету імені Петра Могили комплексу "Києво-Могилянська академія"]. Серія : Державне управління. - 2014. - Т. 239 № 237 . - с. 112.

7. Піщик О.В. Експертне оцінювання пріоритетності програм забезпечення населення житлом [Електронний ресурс] / О.В. Піщик // Проблеми системного підходу в економіці: фаховий зб. наук. праць Національного авіаційного університету. - 2017. - № 2(58). - с. 108. Режим доступу:

http://irbis-nbuv.gov.ua/cgibin/irbis_nbuv/cgiirbis_64.exe?C21COM=2\&I21DBN=UJRN\&P21DBN=UJRN\&IMAGE_FILE_ DOWNLOAD=1\&Image_file_name=PDF/PSPE_print_2017_2_20.pdf.

8. Паливода К.В. Механізми та інструменти фінансування житлового будівництва за умов соціально-економічної нестабільності в Україні [Електронний ресурс] / К.В. Паливода // Інвестиції: практика та досвід. - 2018. - № 1. - с. 7. - Режим доступу: http://irbisnbuv.gov.ua/cgibin/irbis_nbuv/cgiirbis_64.exe?C21COM=2\&I21DBN=UJRN\&P21DBN=UJRN\&IMAGE_FILE_ DOWNLOAD=1\&Image_file_name=PDF/ipd_2018_1_3.pdf.

9. Кривов'язюк І.В. Трансформація сутності та суб'єктна структура регіональних ринків нерухомості на сучасному етапі [Електронний ресурс] / I.В. Кривов'язюк, Н.Ю. Смолярчук // Регіональна економіка. - 2009. - № 1. - с. 238. - Режим доступу: http://irbisnbuv.gov.ua/cgi-

bin/irbis_nbuv/cgiirbis_64.exe?C21COM=2\&I21DBN=UJRN\&P21DBN=UJRN\&IMAGE_FILE_ DOWNLOAD=1\&Image_file_name=PDF/regek_2009_1_31.pdf.

10. Дуброва Н.П. Теоретичні аспекти споживчого та іпотечного кредитування [Електронний ресурс] / Н.П. Дуброва, А.В. Лепеха // Молодий вчений. - 2017. - № 1. - c. 582-585. - Режим доступу: http://nbuv.gov.ua/UJRN/molv_2017_1_141.

\section{References:}

1. Walker, S., \& Marr, J. (2016). Stakeholder power: a winning strategy for building stakeholder commitment and driving corporate growth. Cambridge, Mass.

2. Aliiev, R.A. (2014). Teoretychni aspekty rehionalnoi stratehii rozvytku zhytlovoho budivnytstva [Theoretical aspects of the regional strategy of housing development]. Ekonomichnyi prostir - Economic space, 90, 52. Retrieved from: http://irbis-nbuv.gov.ua/cgibin/irbis_nbuv/cgiirbis_64.exe?C21COM=2\&I21DBN=UJRN\&P21DBN=UJRN\&IMAGE_FILE_ DOWNLOAD=1\&Image_file_name=PDF/ecpros_2014_90_8.pdf [in Ukrainian].

3. Kravchenko, V.P., \& Kravchenko, N.V. (2015). Analiz sotsialnoi polityky Ukrainy ta yii efektyvnist na suchasnomu etapi [Analysis of social policy of Ukraine and its effectiveness at the present stage]. Naukovo-informatsiinyi visnyk Ivano-Frankivskoho universytetu prava imeni Korolia Danyla Halytskoho - Scientific Information Bulletin of Ivano-Frankivsk University of Law named after King Danylo Halytsky, 11, 294. Retrieved from: http://irbis-nbuv.gov.ua/cgibin/irbis_nbuv/cgiirbis_64.exe?C21COM=2\&I21DBN=UJRN\&P21DBN=UJRN\&IMAGE_FILE_ DOWNLOAD=1\&Image_file_name=PDF/Nivif_2015_11_43.pdf [in Ukrainian]. 
4. Kresl, P.K., \& Balwant, S. (2004). The Competitiveness of Cities. Cities and the Global Economy Conference Paper. Melbourne.

5. Romashko, S.M., Savras, I.Z., Selivestov, R.H., \& Yurynets, R.V. (2013). Metodyka Modeliuvannia sotsialno-ekonomichnoho rozvytku terytorii : nauk.-metod. rozrobka - The methodology of Modeling of socio-economic development of territories: the scientific methodological study manual. Kyiv : NADU [in Ukrainian].

6. Orlova, N.S. (2014). Osoblyvosti realizatsii derzhavnoi zhytlovoi polityky v Ukraini [Features of the implementation of state housing policy in Ukraine]. Naukovi pratsi [Chornomorskoho derzhavnoho universytetu imeni Petra Mohyly kompleksu "Kyievo-Mohylianska akademiia"]. Seriia : Derzhavne upravlinnia - Scientific works [Petro Mohyla Black Sea State University of the Kyiv-Mohyla Academy complex]. Series: Public Administration, 239, № 237, 112 [in Ukrainian].

7. Pishchyk, O.V. (2017). Ekspertne otsiniuvannia priorytetnosti prohram zabezpechennia naselennia zhytlom [Expert assessment of the priority of housing programs]. Problemy systemnoho pidkhodu $v$ ekonomitsi: fakhovyi $z b$. nauk. prats Natsionalnoho aviatsiinoho universytetu Problems of system approach in economics: a professional collection of scientific works of the National Aviation University, 2(58), 108. Retrieved from: http://irbis-nbuv.gov.ua/cgibin/irbis_nbuv/cgiirbis_64.exe?C21COM=2\&I21DBN=UJRN\&P21DBN=UJRN\&IMAGE_FILE_ DOWNLOAD=1\&Image_file_name=PDF/PSPE_print_2017_2_20.pdf [in Ukrainian].

8. Palyvoda, K.V. (2018). Mekhanizmy ta instrumenty finansuvannia zhytlovoho budivnytstva za umov sotsialno-ekonomichnoi nestabilnosti v Ukraini [Mechanisms and tools for financing housing construction in conditions of socio-economic instability in Ukraine]. Investytsii: praktyka ta dosvid - Investments: practice and experience, 1, 7. Retrieved from: http://irbisnbuv.gov.ua/cgibin/irbis_nbuv/cgiirbis_64.exe?C21COM=2\&I21DBN=UJRN\&P21DBN=UJRN\&IMAGE_FILE_ DOWNLOAD=1\&Image_file_name=PDF/ipd_2018_1_3.pdf [in Ukrainian].

9. Kryvoviaziuk, I.V., Smoliarchuk, N.Iu. (2009). Transformatsiia sutnosti ta subiektna struktura rehionalnykh rynkiv nerukhomosti na suchasnomu etapi [Transformation of the essence and subject structure of regional real estate markets at the present stage]. Rehionalna ekonomika Regional Economy, 1, 238. Retrieved from: http://irbis-nbuv.gov.ua/cgibin/irbis_nbuv/cgiirbis_64.exe?C21COM=2\&I21DBN=UJRN\&P21DBN=UJRN\&IMAGE_FILE_ DOWNLOAD=1\&Image_file_name=PDF/regek_2009_1_31.pdf [in Ukrainian].

10. Dubrova, N.P., \& Lepekha, A.V. (2017). Teoretychni aspekty spozhyvchoho ta ipotechnoho kredytuvannia [Theoretical aspects of consumer and mortgage lending]. Molodyi vchenyi - Young scientist, 1, 582-585. Retrieved from: http://nbuv.gov.ua/UJRN/molv_2017_1_141 [in Ukrainian]. 